\title{
Alphitonia excelsa (Fenzl) Benth. Leaf Extracts Inhibit the Growth of a Panel of Pathogenic Bacteria
}

\author{
Ian Edwin $\operatorname{Cock}^{1,2, *}$ \\ 'School of Natural Sciences, Griffith University, 170 Kessels Rd, Nathan, Brisbane, Queensland, AUSTRALIA. \\ Environmental Futures Research Institute, Griffith University, 170 Kessels Rd, Nathan, Brisbane, Queensland, AUSTRALIA
}

\begin{abstract}
Introduction: Alphitonia excelsa (Fenzl) Benth. is a large tree that is native to the east coast and northern regions of Australia. Decoctions and infusions produced from the leaves were used by the first Australians to treat a variety of bacterial diseases. Despite this, A. excelsa leaf extractions have not been rigorously examined for antibacterial properties against many pathogens. Methods: The antimicrobial activity of $A$. excelsa leaf extractions was investigated by disc diffusion and growth time course assays against a panel of pathogenic bacteria. The growth inhibitory activity was quantified by MIC determination. Toxicity was determined using the Artemia franciscana nauplii bioassay. Results: Polar to mid-polarity $A$. excelsa leaf solvent extractions inhibited the growth of a wide range of bacterial species. Growth of both gram positive and gram negative bacteria was inhibited by the $A$. excelsa leaf extracts to approximately the same extent. The methanolic extracts were the most potent growth inhibitor against all bacteria tested. The methanolic, aqueous and ethyl acetate $A$. excelsa leaf extracts were particularly potent inhibitors of $P$. mirabilis growth, with MIC values as low as $118 \mu \mathrm{g} / \mathrm{mL}$ for the methanolic extract. A. hydrophilia, $E$. coli, K. pneumonia, S. marcenscens and B. cereus were also particularly susceptible to the methanolic extract, with MIC values generally substantially $<1000 \mu \mathrm{g} / \mathrm{mL}$. The antibacterial activity of the methanolic $A$. excelsa leaf extract was further investigated by growth time course assays which
\end{abstract}

showed significant growth inhibition in cultures of $P$. mirabilis and $B$. cereus within $1 \mathrm{~h}$ of exposure. All extracts were determined to be nontoxic in the Artemia franciscana nauplii bioassay, indicating their safety for internal use as well as for topical uses. Conclusion: The lack of toxicity of the $A$. excelsa leaf extracts and their growth inhibitory bioactivity against a panel of pathogenic bacteria partially validate the traditional usage of this species to treat bacterial diseases and indicate their potential in the development of antiseptic agents.

Key words: Rhamnaceae, Soap tree, Red ash, Australian plants, Antibacterial activity, Medicinal plants.

\section{Correspondence:}

Dr. Ian Edwin Cock

${ }^{1}$ School of Natural Sciences, Griffith University, 170 Kessels Rd, Nathan, Brisbane, Queensland-4111, AUSTRALIA.

${ }^{2}$ Environmental Futures Research Institute, Griffith University, 170 Kessels Rd, Nathan, Brisbane, Queensland-4111, AUSTRALIA.

Phone no: +61737357637

E-mail: I.Cock@griffith.edu.au

DOI: $10.5530 /$ pc.2020.2.14

\section{INTRODUCTION}

Despite many significant advances in the treatment of disease, illnesses caused by bacterial pathogens remain difficult to treat effectively. Many bacterial strains have gained resistance genes and have become either extremely (XDR) or totally drug resistant (TDR) to many antibiotics. ${ }^{1}$ There are now limited therapeutic options for the diseases caused by these pathogens and it is likely that this problem will worsen in the future as bacteria exchange resistance genes and more strains become multi-drug resistant (MDR). The development of alternative antibacterial treatment modalities has become crucial and is considered by the World Health Organisation (WHO) to be one of the most serious challenges facing medical science. ${ }^{2}$ For a number of reasons reviewed elsewhere, ${ }^{1}$ it is unlikely that the previous methods of antibiotic discovery/development will be as successful in the future and new treatment modalities are urgently required.

Plants produce a wide variety of secondary compounds that may provide them with antimicrobial properties. ${ }^{3}$ Traditional plant derived medicines have been used in most parts of the world for a variety of therapeutic purposes, including fighting microbial disease. Indeed, the ability of plant extracts to block the growth of pathogenic bacteria has become the focus of much recent study. ${ }^{4,5}$ Much of the research into traditional medicinal plant use has focused on Asian, ${ }^{6,7}$ African $^{8-12}$ and South American ${ }^{13,14}$ plants. However, the therapeutic potential of the flora of Australia has also received recent attention. The first Australians had well-developed medicinal systems and understood the therapeutic properties of a wide variety of Australian plants and how to use them effectively. ${ }^{15}$ Whilst studies have reported antibacterial activity for some Australian plant species, ${ }^{16-19}$ the antibacterial activity of many Australian native plants remains unexamined.

Alphitonia excelsa (Fenzl) Benth. (Figure 1a; Family Rhamnaceae; commonly known as soap tree or red ash) in an endemic Australian plant that grows in open savannah and forest regions from southern New South Wales through to the northern regions of Queensland and Northern Territory. A. excelsa was used by the first Australians to treat wound infections, diarrhoea and dysentery, eye infections and skin diseases..$^{20,21}$ The antibacterial activity of $A$. excelsa is poorly studied, although one study reported bacteriostatic effects for a methanolic leaf extract against Micrococcus luteus and Salmonella typhimurium. ${ }^{22}$ The same study reported that the extract was completely ineffective against Bacillus subtilis, S. aureus, E. coli and Candida albicans. However, that study examined the growth inhibitory activity of a single high dose $(10 \mathrm{mg} / \mathrm{mL})$. As an MIC at that dosage in many assay systems would be considered to be inactive, the value of this study is doubtful. Furthermore, MIC values were not determined in that study, making a comparison with the efficacy in other studies impossible. Several studies have also reported antibacterial activity for related Excelsa spp. and for compounds isolated from those species. Two triterpenoid saponins isolated from Alphitonia xerocarpus Baill. inhibited the growth of $S$. aureus and Enterococcus faecalis, with MIC values of 4 and $16 \mu \mathrm{g} / \mathrm{mL}$ respectively. ${ }^{23}$ In contrast, the triterpenoids were completely inactive against $E$. coli and $P$. aeruginosa.

Whilst investigations into the chemical composition of $A$. excelsa leaves are generally lacking, several interesting phytochemical components have been identified in other Alphitonia spp. In particular, several triterpenoid components have been identified in Alphitonia petriei (Braid 
and C.T. White), including emmolic acid (Figure 1d), alphitolic acid (Figure 1e), trans-coumaroyl alphitolic acid (Figure 1f), cis-coumaroyl alphitolic acid (Figure 1g), betulinic acid (Figure 1h) and emmolic acid acetate (Figure 1i). ${ }^{24}$ Growth inhibitory properties have previously been reported for many triterpenoids against several bacteria. ${ }^{25}$ Despite these promising studies, examination of the antibacterial properties and phytochemistry of the leaves from A. excelsa is lacking. The current report was undertaken to screen $A$. excelsa leaf extracts for growth inhibitory properties against a panel of pathogenic bacteria.

\section{MATERIALS AND METHODS}

\section{Plant collection and extraction}

Alphitonia excelsa (Fenzl) Benth. leaves were obtained from and identified by Philip Cameron, senior botanic officer, Mt Cootha Botanical Gardens, Brisbane, Australia. Leaf samples were dried in a Sunbeam food dehydrator and stored at $-30^{\circ} \mathrm{C}$. Prior to use, the leaves were freshly ground to a coarse powder and $1 \mathrm{~g}$ quantities were weighed into separate tubes. A volume of $50 \mathrm{~mL}$ methanol, sterile deionised water, ethyl acetate, chloroform or hexane was added to individual tubes and extracted for $24 \mathrm{hr}$ at $4^{\circ} \mathrm{C}$ with gentle shaking. All solvents were obtained from Ajax, Australia and were AR grade. The extracts were filtered through filter paper (Whatman No. 54) under vacuum, followed by drying by rotary evaporation in an Eppendorf concentrator 5301. The resultant pellets were dissolved in $10 \mathrm{~mL}$ sterile deionised water (containing 1\% DMSO). The extracts were passed through $0.22 \mu \mathrm{m}$ filter (Sarstedt) and stored at $4^{\circ} \mathrm{C}$ until use.

\section{Qualitative phytochemical studies}

Phytochemical analysis of the A. excelsa leaf extracts for the presence of phenolic compounds, flavonoids, saponins, triterpenoids, phytosteroids, cardiac glycosides, anthraquinones, tannins and alkaloids was conducted by previously described assays. ${ }^{26-28}$

\section{Antibacterial screening Test microorganisms}

All media was supplied by Oxoid Ltd., Australia. Clinical isolate microbial strains of Aeromonas hydrophilia, Alcaligenes feacalis, Bacillus cereus, Citrobacter freundii, Escherichia coli, Klebsiella pneumoniae, Proteus mirabilis, Pseudomonas fluorescens, Salmonella newport, Serratia marcescens, Shigella sonneii, Staphylococcus aureus, Staphylococcus epidermidis and Streptococcus pyonenes were obtained from Ms. Michelle Mendell and Ms. Jane Gifkins, Griffith University. All stock cultures were subcultured and maintained in nutrient broth at $4^{\circ} \mathrm{C}$.

\section{Evaluation of antimicrobial activity}

Antimicrobial activity of all plant extracts was determined using a modified disc diffusion assay. ${ }^{29-31}$ Briefly, $100 \mu \mathrm{L}$ of each bacterial culture was grown in $10 \mathrm{~mL}$ of fresh nutrient broth until they reached a count of $\sim 10^{8}$ cells $/ \mathrm{mL}$. A volume of $100 \mu \mathrm{L}$ of the bacterial suspension was spread onto nutrient agar plates and extracts were tested for antibacterial activity using $5 \mathrm{~mm}$ sterilised filter paper discs. Discs were infused with $10 \mu \mathrm{L}$ of the plant extracts, allowed to dry and placed onto the inoculated plates. The plates were allowed to stand at $4^{\circ} \mathrm{C}$ for $2 \mathrm{hr}$ before incubation at $37^{\circ} \mathrm{C}$ for $24 \mathrm{hr}$. The diameters of the inhibition zones were measured to the closest whole millimetre. Each assay was performed in at least triplicate. Mean values $( \pm$ SEM) are reported in this study. Standard

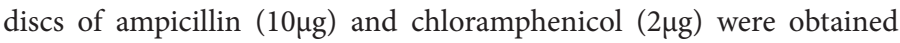
from Oxoid, Australia and were used as positive controls to compare antibacterial activity. Filter discs infused with $10 \mu \mathrm{L}$ of distilled water were used as a negative control.

\section{Minimum inhibitory concentration (MIC) determination}

The minimum inhibitory concentration (MIC) of each extract against susceptible bacteria was determined as previously described. ${ }^{32,33}$ Briefly, the A. excelsa extracts were diluted in deionised water (containing $1 \%$ DMSO) and tested across a range of concentrations. Discs were infused with $10 \mu \mathrm{L}$ of the test dilutions, allowed to dry and placed onto inoculated plates. The assay was completed as outlined above and graphs of the zone of inhibition versus concentration were plotted for each extract. Ln linear regression was used to determine the MIC values of each extract.

\section{Bacterial growth time course assay}

Bacterial growth time course studies were performed as previously described. ${ }^{30,34}$ Briefly, $3 \mathrm{~mL}$ of the $\log$ phase $P$. mirabilis and B. cereus bacterial cultures in nutrient broth were added individually to $27 \mathrm{~mL}$ nutrient broth containing $3 \mathrm{~mL}$ of $10 \mathrm{mg} / \mathrm{mL}$ methanolic plant extract to give a final concentration of $1000 \mu \mathrm{g} / \mathrm{mL}$ in the assay. The tubes were incubated at $37^{\circ} \mathrm{C}$ with gentle shaking. The optical density was measured hourly at $550 \mathrm{~nm}$ for a $6 \mathrm{~h}$ incubation period. Control tubes were incubated under the same conditions but without the extract. All assays were performed in triplicate.

\section{Toxicity screening \\ Reference toxin for toxicity screening}

Potassium dichromate $\left(\mathrm{K}_{2} \mathrm{Cr}_{2} \mathrm{O}_{7}\right)$ (AR grade, Chem-Supply, Australia) was prepared as a $4 \mathrm{mg} / \mathrm{mL}$ solution in distilled water and was serially diluted in artificial seawater for use in the Artemia franciscana nauplii bioassay.

\section{Artemia franciscana nauplii toxicity screening}

Toxicity was tested using an adapted Artemia franciscana nauplii lethality assay ${ }^{35-37}$ Briefly, $400 \mu \mathrm{L}$ of seawater containing approximately 54 (mean 53.7, $n=75$, SD 9.6) A. franciscana nauplii were added to wells of a 48 well plate and immediately used for bioassay. A volume of $400 \mu \mathrm{L}$ of diluted plant extracts or the reference toxin were transferred to the wells and incubated at $25 \pm 1^{\circ} \mathrm{C}$ under artificial light (1000 Lux). A $400 \mu \mathrm{L}$ seawater negative control was run in triplicate for each plate. All treatments were performed in at least triplicate. The wells were checked at regular intervals and the number of dead were counted. The nauplii were considered dead if no movement of the appendages was detected within 10 sec. After $24 \mathrm{hr}$, all nauplii were sacrificed and counted to determine the total $\%$ mortality per well. The $\mathrm{LC}_{50}$ with $95 \%$ confidence limits for each treatment was determined using probit analysis.

\section{Statistical analysis}

Data are expressed as the mean \pm SEM of at least three independent experiments. One way ANOVA was used to calculate statistical significance between control and treated groups with a $P$ value $<0.01$ considered to be statistically significant.

\section{RESULTS}

\section{Liquid extraction yields and qualitative phytochemical screening}

Extraction of $1 \mathrm{~g}$ of dried and powdered $A$. excelsa leaves with solvents of varying polarity yielded dried extracts ranging from $45 \mathrm{mg}$ (hexane extract) to $347 \mathrm{mg}$ (methanolic extract) (Table 1). The aqueous $(285 \mathrm{mg}$ ) and chloroform extracts (140mg) also yielded relatively high levels of extracted materials. The dried extracts were resuspended in $10 \mathrm{~mL}$ of deionised water (containing 1\% DMSO), resulting in the extract concentrations shown in Table 1. Qualitative phytochemical studies 
showed that the high to mid polarity methanol and water solvents extracted the greatest diversity and highest levels of phytochemicals. These extracts contained high levels of polyphenolics and saponins, moderate levels of flavonoids, as well as low levels of alkaloids and tannins. The methanolic extract also contained high levels of phytosterols. Interestingly, despite extracting relatively large amounts of material, the chloroform and hexane extracts were devoid of all classes of phytochemicals screened. Due to their nonpolar nature, these extracts would be expected to contain high levels of lipids, hydrocarbons etc. As our qualitative phytochemical studies did not screen for these compounds, they were not detected. Other techniques are required to further examine the nature of these non-polar components.

\section{Antimicrobial activity}

To determine the growth inhibitory activity of the A. excelsa leaf extracts against the panel of pathogenic bacteria, aliquots $(10 \mu \mathrm{L})$ of each extract were screened in the disc diffusion assay. The A. excelsa leaf extracts inhibited the growth of several gram negative bacterial species (Figure 2). Of the 10 gram negative bacterial strains tested, 6 (60\%) were inhibited by then methanolic $A$. excelsa leaf extract. P. mirabilis and S. marcenscens were most susceptible to the methanolic $A$. excelsa extract, with ZOIs substantially $>8 \mathrm{~mm}$. The aqueous and ethyl acetate extracts also inhibited bacterial growth, albeit with substantially smaller ZOIs, indicating lower potency. The growth of most of the gram positive bacteria was also inhibited by the A. excelsa leaf extracts (Figure 3). The growth of 3 of the $4 \mathrm{~g}$ positive bacteria species screened (75\%) was inhibited by the $A$. excelsa leaf extracts, with only $S$. pyogenes being unaffected. However, in general, only the methanolic A. excelsa leaf extract inhibited the growth of the gram positive bacteria.

The antimicrobial efficacy was further quantified by determining the MIC values for each extract against the microbial species which were determined to be susceptible. The methanolic, aqueous and ethyl acetate A. excelsa leaf extracts were good growth inhibitors of several bacterial species (as judged by MIC; Table 2). P. mirabilis was the most susceptible bacteria to the A. excelsa leaf extracts, with MIC values as low as $118 \mu \mathrm{g} /$ $\mathrm{mL}$ for the methanolic extract (approximately $1 \mu \mathrm{g}$ infused into the disc) recorded for against this bacterium. The MIC values determined for the aqueous and ethyl acetate extract against $P$. mirabilis also indicate moderate growth inhibition (1238 and $984 \mu \mathrm{g} / \mathrm{mL}$ respectively). As $P$. mirabilis infection is a common cause of urinary tract infections and has also been identified as a trigger of rheumatoid arthritis, ${ }^{11,38}$ the methanolic A. excelsa extract has potential for the prevention and treatment of these diseases in genetically susceptible individuals. Furthermore, the methanolic A. excelsa leaf extracts were also a good inhibitor of $K$. pneumomiae growth $(\mathrm{MIC}<1000 \mu \mathrm{g} / \mathrm{mL})$. As K. pneumoniae can trigger ankylosing spondylitis in genetically susceptible individuals, ${ }^{39,12}$ these extracts may also be useful in the prevention and treatment of this disease.

The other bacteria for which the growth inhibitory activity was quantified by MIC determination are generally associated with food poisoning and diarrhoea. Strong growth inhibitory activity was also noted for the

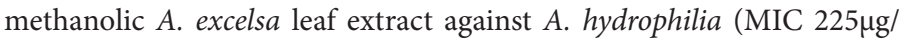
$\mathrm{mL}$ ), E. coli (MIC $415 \mu \mathrm{g} / \mathrm{mL}$ ), B. cereus (MIC $563 \mu \mathrm{g} / \mathrm{mL}$ ) and S. aureus $(\mathrm{MIC} 927 \mu \mathrm{g} / \mathrm{mL})$. The methanolic extract was also a moderate inhibitor of S. newport (MIC $1204 \mu \mathrm{g} / \mathrm{mL}$ ). Therefore, the methanolic extract has potential for the treatment of diarrhoea and gastrointestinal disease. Two other non-gastrointestinal bacteria were also included in this study. S. marcenscens, is an opportunistic pathogen that is most commonly associated with hospital acquired infections, particularly catheter associated bacteremia, urinary tract infections and wound infections. The methanolic, aqueous and ethyl acetate $A$. excelsa leaf extracts were all good inhibitors of $S$. marcenscens growth, with MICs of 155, 863 and $822 \mu \mathrm{g} / \mathrm{mL}$ respectively. Thus, these extracts may also be useful for the treatment of hospital acquired bacterial infections.

Table 1: The mass of dried extracted material, the concentration after resuspension in deionised water and qualitative phytochemical screenings of the $A$. excelsa leaf extracts.

\begin{tabular}{|c|c|c|c|c|c|c|c|c|c|c|c|c|c|c|c|c|c|c|c|}
\hline & & $\frac{\overrightarrow{\vec{g}}}{\text { हो }}$ & & $\begin{array}{l}\frac{n}{O} \\
\frac{c}{d} \\
\frac{c}{\alpha}\end{array}$ & & 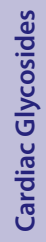 & 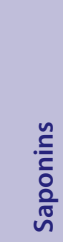 & 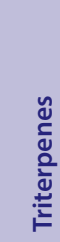 & to & & $\begin{array}{l}\frac{n}{0} \\
\frac{0}{0} \\
\frac{\pi}{2}\end{array}$ & & & $\begin{array}{l}\frac{n}{0} \\
\frac{0}{0} \\
\frac{0}{0} \\
\frac{\pi}{4}\end{array}$ & & & & & \\
\hline 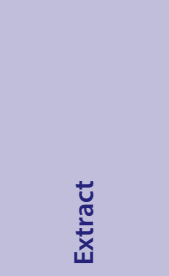 & 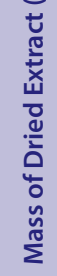 & 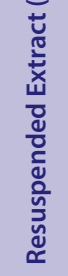 & $\begin{array}{l}\frac{\tilde{y}}{0} \\
\frac{0}{0} \\
\frac{c}{0} \\
\frac{0}{0} \\
\stackrel{0}{0}\end{array}$ & $\begin{array}{l}\frac{0}{0} \\
\frac{0}{3} \\
\frac{0}{0} \\
\text { ம } \\
\frac{1}{0} \\
\frac{1}{0} \\
3\end{array}$ & $\begin{array}{l}\frac{0}{0} \\
\frac{0}{3} \\
0 \\
\frac{n}{5} \\
\bar{d} \\
\frac{\pi}{\pi} \\
3\end{array}$ & 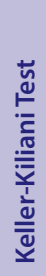 & 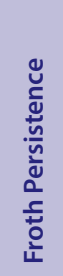 & 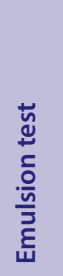 & 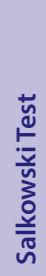 & 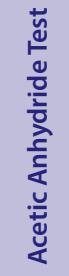 & 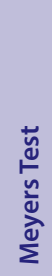 & 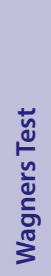 & 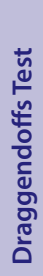 & 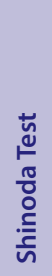 & 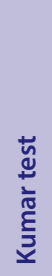 & 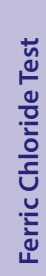 & 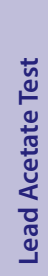 & ષัँ & 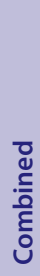 \\
\hline Methanol & 347 & 34.7 & +++ & +++ & +++ & - & ++ & + & + & +++ & ++ & + & + & ++ & ++ & ++ & + & - & - \\
\hline Water & 285 & 28.5 & +++ & +++ & ++ & - & +++ & + & - & - & - & - & - & ++ & ++ & + & + & - & - \\
\hline Ethyl Acetate & 48 & 4.8 & - & - & + & - & - & - & - & - & + & + & + & + & + & - & - & - & - \\
\hline Chloroform & 140 & 14.0 & - & - & - & - & - & - & - & - & - & - & - & - & - & - & - & - & - \\
\hline Hexane & 45 & 4.5 & - & - & - & - & - & - & - & - & - & - & - & - & - & - & - & - & - \\
\hline
\end{tabular}

+++ indicates a large response; ++ indicates a moderate response; + indicates a minor response; - indicates no response in the assay. 


\section{Bacterial growth time course assay}

The most susceptible gram negative ( $P$. mirabilis) and gram positive $(B$. cereus) bacterial species were selected for further study by growth time course assays in the presence and absence of the extract. Only the effect of the methanolic extract on the bacterial growth time courses was evaluated as this extract was generally more potent than the other A. excelsa extracts. The starting concentration of the extract used in these assays was $1000 \mu \mathrm{g} / \mathrm{mL}$. The methanolic A. excelsa extract significantly inhibited P. mirabilis (Figure 4a) and B. cereus (Figure $4 \mathrm{~b}$ ) growth within $1 \mathrm{~h}$, indicating a rapid antimicrobial action. Whilst both $P$. mirabilis and $B$. cereus growth was inhibited for at least the first $4 \mathrm{hr}$ of the time course, the bacteria were generally able to overcome this inhibition by $6 \mathrm{~h}$, with the recorded turbidity not significantly different to that of the untreated control. This indicates that the growth inhibition of these bacteria was bacteriostatic for the methanolic A. excelsa extract at the concentrations tested against these bacteria.

\section{Quantification of toxicity}

The toxicity of the A. excelsa extracts was initially tested in the Artemia franciscana nauplii bioassay at a concentration of $1000 \mu \mathrm{g} / \mathrm{mL}$

Table 2: Minimum bacterial growth inhibitory concentration $(\mu \mathrm{g} / \mathrm{mL})$ of the $A$. excelsa leaf extracts against susceptible bacterial species.

\begin{tabular}{|c|c|c|c|c|c|}
\hline \multirow{2}{*}{ Bacterial species } & \multicolumn{5}{|c|}{ A. excelsa Extract } \\
\hline & Methanol & Water & Ethyl Acetate & Chloroform & Hexane \\
\hline \multicolumn{6}{|l|}{ Gram negative } \\
\hline A. faecalis & - & - & - & - & - \\
\hline A. hydrophilia & 225 & 326 & 280 & - & - \\
\hline C. freundi & - & - & - & - & - \\
\hline E. coli & 415 & 826 & 684 & - & - \\
\hline K.pneumoniae & 866 & - & - & - & - \\
\hline P. mirabilis & 118 & 1238 & 984 & - & - \\
\hline P. fluroscens & - & - & - & - & - \\
\hline S. newport & 1204 & - & - & - & - \\
\hline S. marcenscens & 155 & 863 & 822 & - & - \\
\hline S. sonnei & - & - & - & - & - \\
\hline \multicolumn{6}{|l|}{ Gram positive } \\
\hline B. cereus & 563 & 3280 & 1350 & - & - \\
\hline S. aureus & 927 & 3870 & - & - & - \\
\hline S. epidermidis & 1428 & - & - & - & - \\
\hline S. pyogenes & - & - & - & - & - \\
\hline
\end{tabular}

Numbers indicate the mean MIC values of triplicate determinations. - indicates no inhibition.

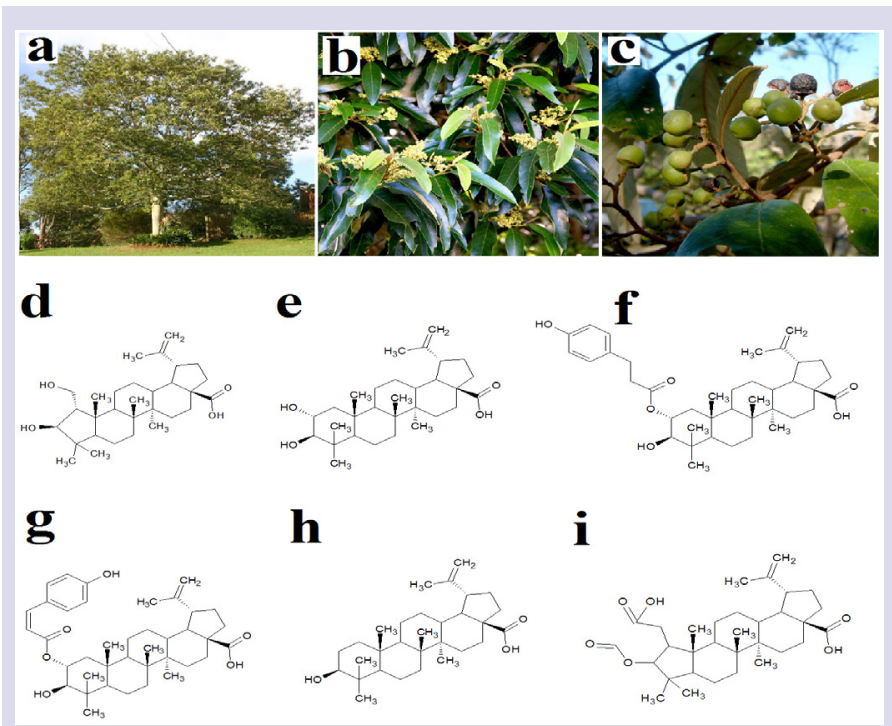

Figure 1: A. excelsa (a) whole tree, (b) leaves and flowers and (c) fruit, as well as the chemical structures of (d) emmolic acid, (e) alphitolic acid, (f) trans-coumaroyl alphitolic acid, (g) cis-coumaroyl alphitolic acid, (h) betulinic acid, (i) emmolic acid acetate.

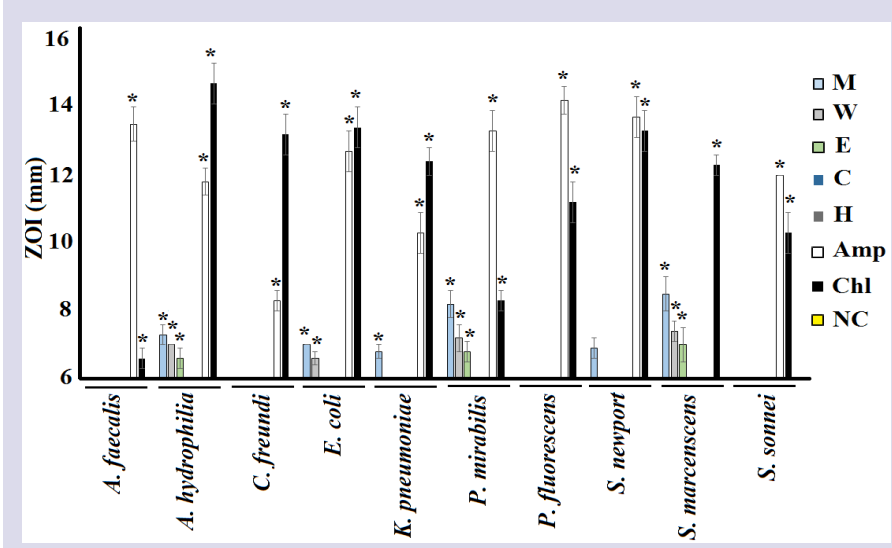

Figure 2: Growth inhibitory activity of $A$. excelsa leaf extracts against the gram negative bacterial species measured as zones of inhibition $(\mathrm{mm}) \pm$ SEM. $M$ = methanolic extract; $\mathrm{W}=$ aqueous extract; $\mathrm{E}=$ ethyl acetate extract; $\mathrm{C}=$ chloroform extract; $\mathrm{H}=$ hexane extract; $\mathrm{Amp}=$ ampicillin $(10 \mu \mathrm{g})$ control; $\mathrm{Chl}=$ chloramphenicol $(2 \mu \mathrm{g})$ control; $^{*}=$ results that are significantly different to the untreated control $(P<0.5)$. All determinations were in at least triplicate and the results are expressed as mean zones of inhibition $(\mathrm{mm})$ \pm SEM. 
(Figure 5). All extracts induced $<50 \%$ mortality at 24 and $48 \mathrm{hr}$ and were thus deemed to be non-toxic. In contrast, the potassium dichromate positive control induced mortality within $4 \mathrm{~h}$ (results not shown), with $100 \%$ mortality induction seen by $24 \mathrm{hr}$. All extracts were determined to be nontoxic, with $\mathrm{LC}_{50}$ values substantially greater than $1000 \mu \mathrm{g} / \mathrm{mL}$ following $24 \mathrm{hr}$ exposure. Extracts with an $\mathrm{LC}_{50}$ of greater than $1000 \mu \mathrm{g} /$ $\mathrm{mL}$ towards Artemia nauplii have previously been defined as being nontoxic. ${ }^{38}$

\section{DISCUSSION}

Despite the initial potency of many antibiotic chemotherapies, recent increases in bacterial resistance has made the development of new antibiotic therapies a high priority. ${ }^{1} \mathrm{~A}$ parallel decrease in the introduction of new antibiotic therapies in recent years has further compounded this problem. As a result, interest in re-evaluating medicinal plants for new antibiotic chemotherapies has escalated substantially. The first Australians used $A$. excelsa to treat multiple diseases and infections caused by bacterial pathogens. ${ }^{20,21}$ Despite this, limited scientific evaluations have rigorously evaluated the antibacterial properties of $A$. excelsa.

Our study examined the ability of $A$. excelsa leaf extracts to inhibit the growth of a panel of medicinally important bacterial pathogens. The methanolic extract was a particularly potent inhibitor of $P$. mirabilis with an MIC value of $118 \mu \mathrm{g} / \mathrm{mL}$. The aqueous, ethyl acetate extract and chloroform extracts were also moderate $P$. mirabilis growth inhibitors, albeit with higher MIC values (1238 and $984 \mu \mathrm{g} / \mathrm{mL}$ respectively). As P. mirabilis can trigger rheumatoid arthritis in genetically susceptible individuals, ${ }^{11,39}$ these extracts have potential for the development of rheumatoid arthritis inhibitory therapies. The methanolic extract also displayed good $K$. pneumoniae growth inhibitory properties (MIC $866 \mu \mathrm{g} / \mathrm{mL}$ ). As K. pneumoniae can trigger ankylosing spondylitis in genetically susceptible individuals, ${ }^{39,12}$ this extract may also be useful in the prevention and treatment of ankylosing spondylitis. The methanolic A. excelsa leaf extract was also a good inhibitor of bacterial pathogens associated with food poisoning and diarrhoea. Strong growth inhibitory activity was also noted for the methanolic $A$. excelsa leaf extract against

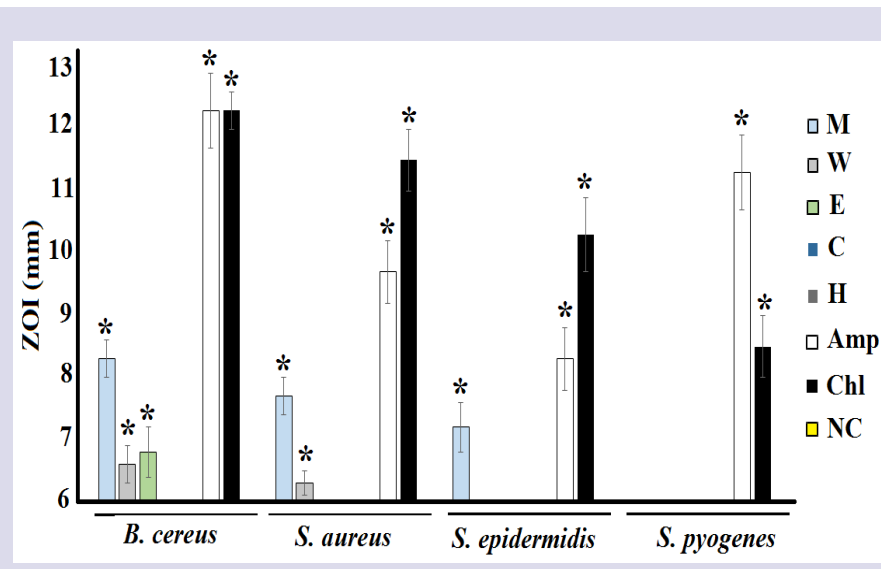

Figure 3: Growth inhibitory activity of $A$. excelsa leaf extracts against the gram positive bacterial species measured as zones of inhibition $(\mathrm{mm}) \pm$ SEM. $M=$ methanolic extract; $W=$ aqueous extract; $E$ = ethyl acetate extract; $\mathrm{C}=$ chloroform extract; $\mathrm{H}=$ hexane extract; $\mathrm{Amp}=$ ampicillin $(10 \mu \mathrm{g})$ control; $\mathrm{Chl}=$ chloramphenicol $(2 \mu \mathrm{g})$ control; $^{*}=$ results that are significantly different to the untreated control $(P<0.5)$. All determinations were in at least triplicate and the results are expressed as mean zones of inhibition $(\mathrm{mm})$ \pm SEM.
A. hydrophilia (MIC $225 \mu \mathrm{g} / \mathrm{mL}$ ), E. coli (MIC $415 \mu \mathrm{g} / \mathrm{mL}$ ), B. cereus (MIC $563 \mu \mathrm{g} / \mathrm{mL}$ ) and S. aureus (MIC $927 \mu \mathrm{g} / \mathrm{mL}$ ). The methanolic extract was also a moderate inhibitor of $S$. newport (MIC $1204 \mu \mathrm{g} / \mathrm{mL}$ ). Therefore, the methanolic extract has potential for the treatment of diarrhoea and gastrointestinal disease. Similarly, the methanolic A. excelsa leaf extract was also a good inhibitor of the growth of the opportunistic pathogen $S$. marcenscens. The bacterium is commonly associated with hospital acquired infections, particularly catheter associated bacteremia, urinary tract infections and wound infections. The methanolic, aqueous and ethyl acetate A. excelsa leaf extracts were all good inhibitors of $S$. marcenscens growth, with MICs of 155,863 and $822 \mu \mathrm{g} / \mathrm{mL}$ respectively. Thus, these extracts may also be useful for the treatment of hospital acquired bacterial infections.

The ability of the A. excelsa leaf extracts to inhibit the growth of both gram-positive and gram-negative bacteria is in agreement with previous reports of the antibacterial activity of other Australian plant species. $^{40,41}$ In this study, the gram-negative and gram-positive bacteria were approximately equally susceptible to the A. excelsa leaf extracts. In contrast, many previous studies have reported substantially greater susceptibility for gram-positive bacteria to South American, ${ }^{42,43}$ African $^{11,39}$ and Australian ${ }^{44}$ plant extracts. Results within our laboratory have also confirmed the greater susceptibility of gram-positive bacteria towards many other Australian plant extracts. ${ }^{44,45}$ The gram-negative bacterial cell wall outer membrane is thought to act as a barrier to many substances including several antibiotics. ${ }^{46}$ In contrast, other studies have demonstrated that gram-negative bacteria are often as susceptible
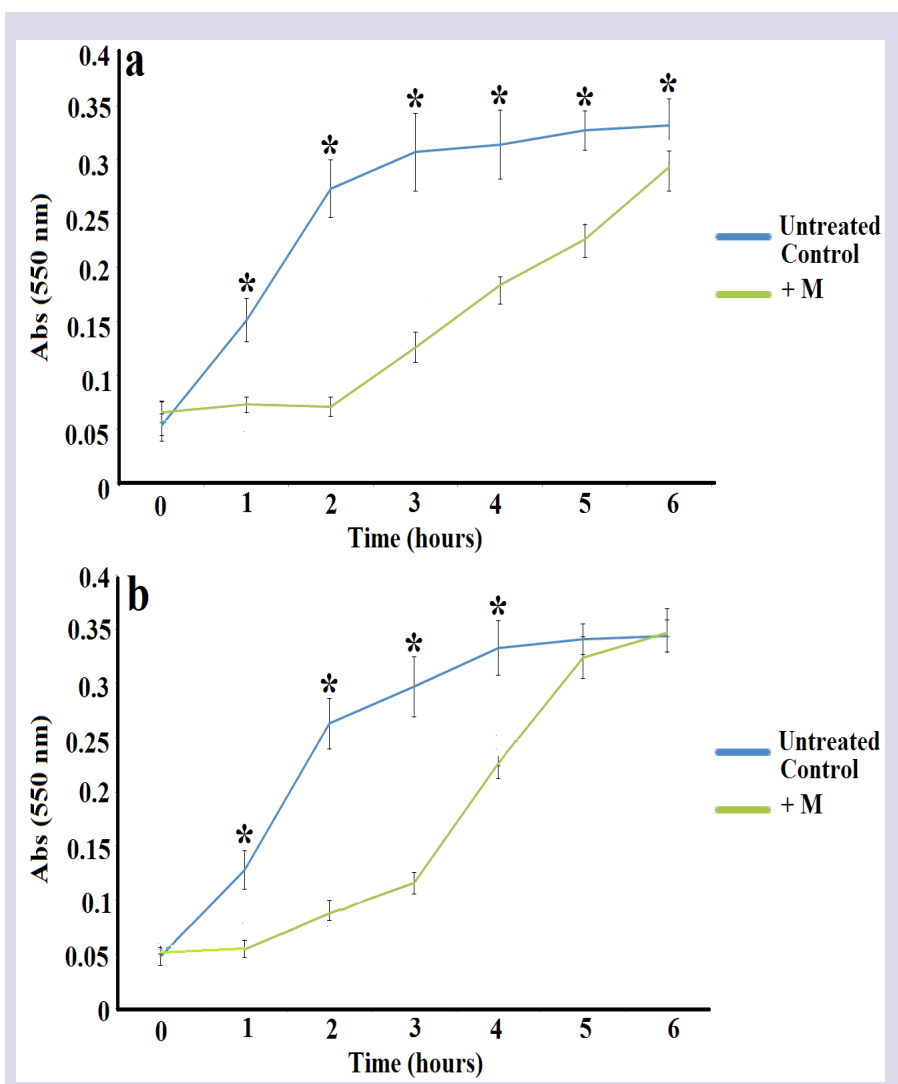

Figure 4: Bacterial growth curves for the methanolic and aqueous $A$. excelsa leaf extract against (a) P. mirabilis, (b) B. cereus. All bioassays were performed in at least triplicate and are expressed as mean \pm SEM. ${ }^{*}=$ growth results in the presence of the methanolic extract that are significantly different to the untreated control growth $(p<0.01)$. 


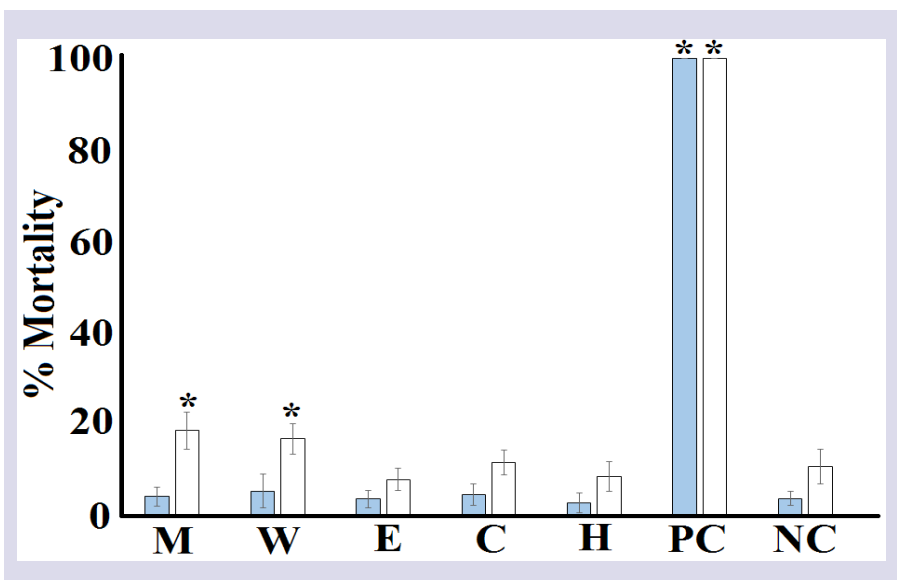

Figure 5: The lethality of the $A$. excelsa leaf extracts $(1000 \mu \mathrm{g} / \mathrm{mL})$, potassium dichromate $(1000 \mu \mathrm{g} / \mathrm{mL})$ and a seawater control. Blue bars represent the $\%$ mortality following $24 \mathrm{hr}$ exposure to the extract/toxin. White bars represent the $\%$ mortality following $48 \mathrm{hr}$ exposure to the extract/toxin. NC $=$ negative (seawater) control; $\mathrm{PC}=$ positive control $(1000 \mu \mathrm{g} / \mathrm{mL}$ potassium dichromate). All bioassays were performed in at least triplicate and are expressed as mean \pm SEM. * indicates results that are significantly different to the negative controls $(P<0.5)$.

(or more susceptible) to plant extracts from different Australian plant species. ${ }^{30,28}$

Whilst a detailed investigation of the phytochemistry of the A. excelsa leaf extracts was beyond the scope of our study, qualitative screening studies were used to determine the classes of compounds present. Some commonalities were noted: the most potent aqueous and methanolic extracts all contained relatively high levels of total phenolics and flavonoids. It is likely that these and other phytochemical classes may contribute to the growth inhibitory properties of these extracts. Our qualitative phytochemical screening studies also indicated that triterpenoids, phytosterols and saponins were present in the A. excelsa leaf extracts. Furthermore, previous studies have also identified a number of triterpenoids in Alphitonia spp. Extracts. ${ }^{24}$ Many studies have reported potent antibacterial activities for a wide variety of these compounds. ${ }^{25}$ Further phytochemical evaluation studies and bioactivity driven isolation of active components is required to further evaluate the mechanism of bacterial growth inhibition.

It is likely that other phytocompounds may also contribute to the antibacterial properties of $A$. excelsa. Monoterpenoids including a-pinene, $\beta$-pinene, sabinene, mycrene, terpinene, limonene, piperitone and $\beta$-phellandrene also inhibit the growth multiple bacteria, including several antibiotic resistant strains of Enterobacteriaceae. ${ }^{25}$ The antibacterial activities for several sesquiterpenoids including $\alpha$-cubebene, copaene and caryophyllene have also been reported..$^{25}$ Similarly, many tannin compounds have bacterial growth inhibitory activity. Gallotannins inhibit the growth of a broad spectrum of bacterial species ${ }^{47}$ through a variety of mechanisms including binding cell surface molecules including lipotoichoic acid and proline-rich cell surface proteins, ${ }^{43,48}$ and by inhibiting glucosyltransferase enzymes. ${ }^{45}$ Elligitannins are also highly potent inhibitors of bacterial growth, with MIC values as low as $62.5 \mu \mathrm{g} / \mathrm{mL} .{ }^{49,50}$ Ellagitannins have also been reported to function via several antibiotic mechanisms including interaction with cytoplasmic oxidoreductases and by disrupting bacterial cell walls. ${ }^{49,51}$ Thus, it is likely that multiple compounds within the A. excelsa leaf extracts are contributing to the antibacterial activity reported here.

The findings of this study also demonstrate that the A. excelsa leaf extracts were nontoxic towards Artemia franciscana nauplii, with $\mathrm{LC}_{50}$ values substantially $>1000 \mu \mathrm{g} / \mathrm{mL}$. Extracts with $\mathrm{LC}_{50}$ values $>1000 \mu \mathrm{g} /$ $\mathrm{mL}$ towards Artemia nauplii are defined as being nontoxic. ${ }^{37}$ Whilst our preliminary toxicity studies indicate that these extracts may be safe for therapeutic use, studies using human cell lines are required to further evaluate the safety of these extracts. Furthermore, whilst these studies have demonstrated the potential of the A. excelsa leaf extracts in the development of future antibiotic chemotherapeutics for the prevention and treatment of urinary tract infections, autoimmune diseases (particularly rheumatoid arthritis and ankylosing spondylitis) and gastrointestinal diseases, more work is required to isolate the inhibitory components and determine the mechanism of inhibition.

\section{CONCLUSION}

The results of this study demonstrate the potential of the A. excelsa leaf extracts as inhibitors of pathogenic bacteria growth. Furthermore, their lack of toxicity indicates than they are safe for internal as well as topical treatment. Further studies aimed at the purification and identification of bioactive components are required to examine the mechanisms of action of these agents.

\section{ACKNOWLEDGEMENT}

The authors are grateful to Philip Cameron for providing the A. excelsa leaves used in this study and to Michelle Mendell and Jane Gifkins for the gift of the clinical isolate bacterial strains. Financial support for this work was provided by the Environmental Futures Research Institute and the School of Natural Sciences, Griffith University, Australia.

\section{CONFLICT OF INTEREST}

The author report no conflicts of interest.

\section{ABBREVIATIONS}

DMSO: Dimethyl sulfoxide; $\mathbf{L C}_{50}$ : The concentration required to achieve $50 \%$ mortality; MIC: minimum inhibitory concentration.

\section{REFERENCES}

1. Cheesman MJ, llanko A, Blonk B, et al. Developing new antimicrobial therapies: Are synergistic combinations of plant extracts/compounds with conventional antibiotics the solution?. Pharmacogn Rev. 2017;11(22):57-72. DOI: 10.4103/ phrev.phrev_21_17

2. WHO. Antimicrobial Resistance. World Health Organization. 2016. Available from: http://www.who.int/mediacentre/factsheets/fs194/en/. [Cited on 2017 May 10].

3. Cowan MM. Plant products as antibacterial agents. Clin Microbiol Rev. 1999;12(4):564-82.

4. Bhavnani SM, Ballow CH. New agents for Gram-positive bacteria. Curr Opin Microbiol. 2000;3(5):528-34

5. Chiariandy $\mathrm{CM}$, Seaforth $\mathrm{CE}$, Phelps $\mathrm{RH}$, et al. Screening of medicinal plants from Trinidad and Tobago for antimicrobial and insecticidal properties. J Ethnopharmacol. 1999;64(3):265-70.

6. Hart C, Cock IE. An examination of the antimicrobial and anticancer properties of Garcinia cambogia fruit pericarp extracts. BEMS Reports. 2016;2(1):23-6. DOI: 10.5530/BEMS.2016.1.5

7. Wright MH, Arnold MSJ, Lee CJ, et al. Qualitative phytochemical analysis and antibacterial activity evaluation of Indian Terminalia spp. against the pharyngitis causing pathogen Streptococcus pyogenes. Pharmacogn Commun. 2016;6(2):85-92. DOI: 10.5530/pc.2016.2.6

8. Hübsch Z, Zyl RLV, Cock IE, et al. Interactive antimicrobial and toxicity profiles of conventional antimicrobials with Southern African medicinal plants. S Afr J Bot. 2014;93:185-97. DOI: 10.1016/j.sajb.2014.04.005

9. Arkhipov A, Sirdaarta J, Rayan $\mathrm{P}$, et al. An examination of the antibacterial, antifungal, anti-Giardial and anticancer properties of Kigelia africana fruit extracts. Pharmacogn Commun. 2014;4(3):62-76. DOI: 10.5530/pc.2014.3.7

10. Rabadeaux $C$, Vallette $L$, Sirdaarta J, et al. An examination of the antimicrobial and anticancer properties of Khaya senegalensis (Desr.) A.Juss. bark extracts. Pharmacogn J. 2017;9(2):175-84. DOI: 10.5530/pj.2017.4.82

11. Cock IE, Vuuren SFV. Anti-Proteus activity of some South African medicinal 
plants: Their potential for the treatment and prevention of rheumatoid arthritis. Inflammopharmacol. 2014;22(1):23-36. DOI 10.1007/s10787-013-0179-3

12. Cock IE, Vuuren SFV. The potential of selected some South African plants with anti-Klebsiella activity for the treatment and prevention of ankylosing spondylitis. Inflammopharmacol. 2015;23(1):21-35. DOI: 10.1007/s-10787-0130179-3

13. Mohanty S, Cock IE. Evaluation of the antibacterial activity and toxicity of Myrciaria caulifloria methanolic leaf and fruit extracts. Int J Microbiol. 2009;7(2).

14. Paz EA, Cerdeiras MP, Fernandez J, et al. Screening of Uruguayan medicinal plants for antimicrobial activity. J Ethnopharmacol. 1995;45(1):67-70.

15. Cock IE. Medicinal and aromatic plants: Australia. In Ethnopharmacology: Encyclopedia of Life Support Systems (EOLSS). 2011. Developed under the auspices of UNESCO. Oxford, UK: EOLSS Publishers. 2011. Available from: http://www. eolss.net.

16. Sirdaarta J, Matthews B, Cock IE. Inhibitory activity of Kakadu plum fruit extracts against microbial triggers of rheumatoid arthritis: Identification of stilbene and tannin components. J Funct Foods. 2015;17:610-20. DOI: 10.1016/j. jff.2015.06.019

17. Winnett $\mathrm{V}$, Sirdaarta J, White A, et al. Inhibition of Klebsiella pneumonia growth by selected Australian plants: Natural approaches for the prevention and management of ankylosing spondylitis. Inflammopharmacol. 2017;25(2):22335. DOI: 10.1007/s10787-017-0328-1

18. Wright MH, Matthews B, Arnold MSJ, et al. The prevention of fish spoilage by high antioxidant Australian culinary plants: Shewanella putrefaciens growth inhibition. Int J Food Sci and Technol. 2016;51(3):801-13. DOI: 10.1111/ijfs.13026

19. Ilanko A, Cock IE. The interactive antimicrobial activity of conventional antibiotics and Petalostigma spp. Extracts against bacterial triggers of some autoimmune inflammatory diseases. Pharmacogn J. 2019;11(2):292-309. DOI: 10.5530/pj.2019.11.45

20. Lassak EV, McCarthy TM. Australian medicinal plants: A complete guide tom identification and usage. Reed New Holland Publishers Sydney Australia. 2011;303.

21. Cock IE. Medicinal and aromatic plants: Australia. In Ethnopharmacology, Encyclopedia of Life Support Systems (EOLSS). Developed under the auspices of UNESCO. Oxford, UK: EOLSS Publishers. 2011. Available from: http://www. eolss.net.

22. Smyth T, Ramach VN, Brooks P, Smyth WF. A study of the antibacterial activities of selected Australian medicinal plants. Journal of Pharmacognosy and Phytotherapy. 2009;1(6):82-6.

23. Muhammad D, Lalun N, Bobichon H, Debar EL, Gangloff SC, Nour M, et al. Triterpenoids from the leaves of Alphitonia xerocarpus Baill and their biological activity. Phytochemistry. 2016;129:45-57.

24. Raju R, Gunawardena D, Ahktar M, Low M, Reddell P, Münch G. Anti-inflammatory chemical profiling of the Australian rainforest tree Alphitonia petriei (Rhamnaceae). Molecules. 2016;21(11):1521.

25. Cock IE. The phytochemistry and chemotherapeutic potential of Tasmania lanceolata (Tasmanian pepper): A review. Pharmacogn Commun. 2013;3(4):1-13. DOI: $10.5530 /$ pc.2013.4.3

26. Arkhipov A, Sirdaarta J, Rayan $P$, et al. An examination of the antibacterial, antifungal, anti-Giardial and anticancer properties of Kigelia africana fruit extracts. Pharmacogn Commun. 2014;4(3):62-76. DOI: 10.5530/pc.2014.3.7

27. Kalt FR, Cock IE. Gas chromatography-mass spectroscopy analysis of bioactive Petalostigma extracts: Toxicity, antibacterial and antiviral activities. Pharmacogn Mag. 2014;10(Suppl 1):S37-49. DOI: 10.4103/0973-1296.127338

28. Vesoul J, Cock IE. The potential of Bunya nut as an antibacterial food agent Pharmacogn Commun. 2012;2(1):72-9. DOI: 10.5530/pc.2012.1.13

29. Courtney R, Sirdaarta J, Matthews B, et al. Tannin components and inhibitory activity of Kakadu plum leaf extracts against microbial triggers of autoim- mune inflammatory diseases. Pharmacogn J. 2015;7(1):18-31. DOI: 10.5530/ pj.2015.7.2

30. Cock IE. Antimicrobial activity of Acacia aulacocarpa and Acacia complanta methanolic extracts. Pharmacogn Commun. 2012;2(1):66-71. DOI: 10.5530/ pc.2012.1.12

31. Wright MH, Shalom J, Matthews B, et al. Terminalia ferdinandiana Exell: Extracts inhibit Shewanella spp. growth and prevent fish spoilage. Food Microbiol. 2019;78:114-22. DOI: 10.1016/j.fm.2018.10.006

32. Sautron C, Cock IE. Antimicrobial activity and toxicity of Syzygium australe and Syzygium leuhmanii fruit extracts. Pharmacogn Commun. 2014;4(1):53-60. DOI: 10.5530/pc. 2014.1 .8

33. Hart C, Ilanko P, Sirdaarta J, et al. Tasmannia stipitata as a functional food/ natural preservative: Antimicrobial activity and toxicity. Pharmacogn Commun. 2014;4(4):33-47. DOI: 10.5530/pc.2014.4.4

34. Bryant K, Cock IE. Eupomatia laurina R.Br. fruit solvent extractions inhibit the growth of a panel of pathogenic bacteria. Pharmacognosy Communications. 2017;7(1):16-23. DOI: 10.5530/pc.2017.1.3

35. Cock IE. Assessment of the toxicity of selected Australian native plant extracts using the Artemia franciscana nauplii bioassay. Int J Toxicol. 2008;5(2):2.

36. Ruebhart DR, Wikramasinghe WA, Cock IE. Protective efficacy of the antioxidants vitamin $\mathrm{E}$ and Trolox against Microcystis aeruginosa and microcystin-LR in Artemia franciscana nauplii. J Toxicol Environ Health Part A. 2009;72(24):156775.

37. Cock IE, Ruebhart DR. Comparison of the brine shrimp nauplii bioassay and the ToxScreen-II test for the detection of toxicity associated with Aloe vera (Aloe barbadensis Miller) leaf extract. Pharmacognosy Research. 2009;1(2):98-101.

38. Ebringer A, Rashid T. Rheumatoid arthritis is an autoimmune disease triggered by Proteus urinary tract infection. Clin Develop Immunol. 2006;13(1):41-8.

39. Ebringer A, Rashid T, Wilson C, et al. Ankylosing spondylitis as an auto-immune disease linked to intestinal Klebsiella infection: Prospects for a new therapeutic approach. Current Rheumatology Reviews. 2006;2:55-68.

40. Cock IE. Antibacterial activity of selected Australian plant species. The Int $J$ Microbiol. 2008:6:1-12.

41. Kalt FR, Cock IE. The medicinal potential of Australian native plants from Toohey Forest, Australia. SPJNS. 2011;28:1-22.

42. Mohanty S, Cock IE. Evaluation of the antibacterial activity and toxicity of Myrciaria caulifloria methanolic leaf and fruit extracts. Int J Microbiol. 2009;7(2).

43. Paz EA, Cerdeiras MP, Fernandez J, et al. Screening of Uruguayan medicinal plants for antimicrobial activity. J Ethnopharmacol. 1995;45(1):67-70.

44. Waage SK, Hedin PA. Quercetin 3-O-galactosyl-(1, 4, 6)-glucoside, a compound from narrow leaf vetch with antibacterial activity. Phytochem. 1985;24(2):243-5.

45. Palombo EA, Semple SJ. Antibacterial activity of traditional Australian medicinal plants. J Ethnopharmacol. 2001;77(2-3):151-7.

46. Cock IE. Antimicrobial activity of Eucalyptus major and Eucalyptus baileyana methanolic extracts. Int J Microbiol. 2009;6(1):31.

47. Chikowe G, Mpala L, Cock IE. Antibacterial activity of selected Australian Syzygium species. Pharmacogn Commun. 2013;3(4):77-83. DOI: 10.5530/ pc.2013.4.11

48. Tortora GJ, Funke BR, Case CL. Microbiology: An Introduction, Benjamin Cummings, San Francisco. 2001

49. Buzzini $P$, Arapitsas $P$, Goretti $M$, et al. Antimicrobial activity of hydrolysable tannins. Mini-Rev Med Chem. 2008;8(12):1179-87.

50. Wolinsky LE, Sote EO. Isolation of natural plaque-inhibiting substances from 'Nigerian chewing sticks. Caries Res. 1984;18(3):216-25.

51. Hogg SD, Embery G. Blood-group-reactive glycoprotein from human saliva interacts with lipoteichoic acid on the surface of Streptococcus sanguis cells. Arch Oral Biol. 1982:27(3):261-8.

\section{SUMMARY}

- A. excelsa leaf extracts were screened for the ability to block the growth of a panel of bacterial pathogens.

- The growth inhibition of both gram-positive and gram-negative bacteria was tested.

- The antibacterial activity was quantified by determining the MIC values of each extract.

- $\quad$ Growth time course studies were also undertaken against P. mirabilis and B. cereus.

- $\quad$ Toxicity of the A. excelsa leaf extracts was determined using the Artemia nauplii toxicity bioassay. 
PICTORIAL ABSTRACT

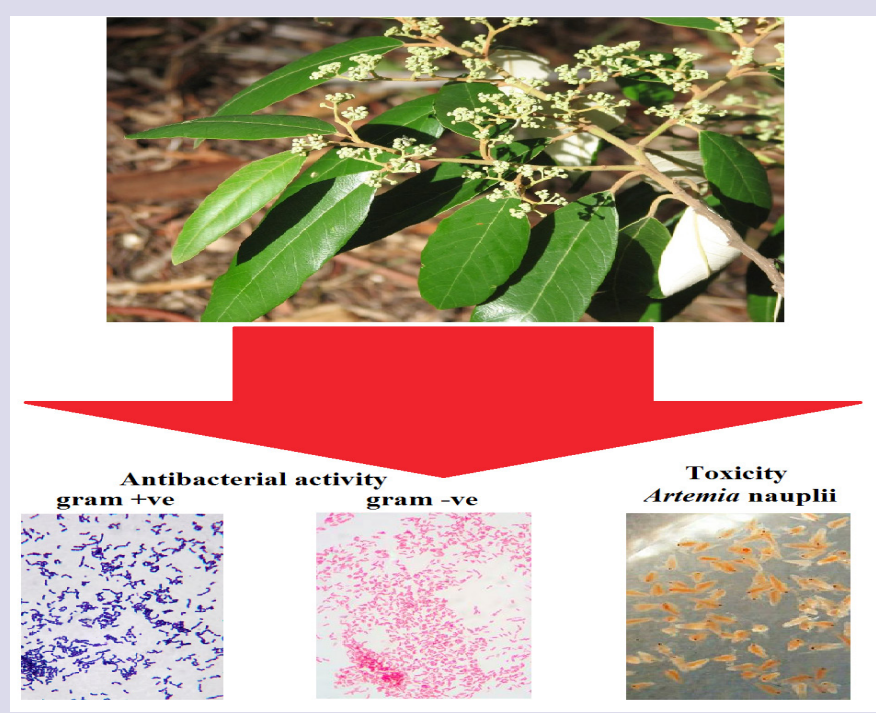

\section{ABOUT AUTHORS}

Dr. Ian Cock leads a research team in the Environmental Futures Research Institute and the School of Natural Sciences at Griffith University, Australia. His research involves bioactivity and phytochemical studies into a variety of plant species of both Australian and international origin, including Aloe vera, South Asian and South American tropical fruits, as well as Australia plants including Scaevola spinescens, Pittosporum phylliraeoides, Terminalia ferdinandiana (Kakadu plum), Australian Acacias, Syzygiums, Petalostigmas and Xanthorrhoea johnsonii (grass trees). This range of projects has resulted in nearly 200 publications in a variety of peer reviewed journals. 